\title{
In-phase multiaxial fatigue experimental analysis of welded cylindrical 6063-T66 aluminium alloy specimens
}

Peter Kopas, Milan Sága

Department of Applied Mechanics, Faculty of Mechanical Engineering, University of Žilina, Univerzitná 1, 01026 Žilina, Slovak Republic.peter.kopas@fstroj.uniza.sk, milan.saga@fstroj.uniza.sk

This paper is concerned with an experimental and numerical study of the fatigue behaviour of cylindrical 6063T66 welded specimens subjected to biaxial loading. In-phase torsion-bending fatigue tests under constant amplitude loading were performed in a standard electromechanical machine with a suitable gripping system. The experimental part was focused on the modeling of combined biaxial loading and determining the number of cycles to fracture in the region of low-cycle fatigue. In-phase loading can be treated fairly well using the conventional hypotheses (von Mises or Tresca) on basis of the nominal, structural or local strains or stresses. Based on the experimental results the fatigue design curves are compared to the fatigue data from base metal and weldments.

Keywords: multiaxial fatigue, computational analysis, experimental analysis, aluminium alloy, welding

\section{Acknowledgements}

This work has been supported by VEGA grant No. 1/1089/11 and KEGA grant No. 004ŽU-4/2012. The authors gratefully acknowledge this support.

\section{References}

[1] BANNANTINE, J. A., SOCIE, D. F., (1992). A multiaxial fatigue life estimation technique. In: Advances in Fatigue Lifetime Predictive Techniques, ASTM STP 1122. Eds: M. R. Mitchell a R. W. Landgraf. Philadelphia, American Society for Testing and Materials, pp. 249-275.

[2] ROSENBERG, G., JUHAR, L. (2012). Fatigue resistance of dual phase steels in presence of microstructural inhomogeneities. Manufacturing Technology 2012, Vol. 12, No. 13, pp. 217-221, ISSN 1213-2489

[3] BATHE, K. J. (1982). Finite Element Procedures. New Jersey, Prentice Hall, 1982.

[4] CHEN, H., SHANG, D. G., TIAN, Y. J., LIU, J.-Z. (2011). Comparison of multiaxial fatigue damage models under variable amplitude loading. Journal of Mechanical Science and Technology 26 (11), pp. 3439-3446.

[5] JAKUBOVIČOVÁ, L., VAŠKO, M., KOMPIŠ, V. (2003). Trefftz Functions Using the Fundamental Solution with the Singularity Outside the Domain. In Computer Assisted Mechanics and Engineering Sciences. 2003, Vol. 10, No. 4, p. 515-521. ISSN 1232-308X.

[6] LI, J., ZHANG, Z., SUN, Q., LI, C. Low-cycle fatigue life prediction of various metallic materials under multiaxial loading. Fatigue and Fracture of Engineering Materials and Structures 34 (4), pp. 280-290.

[7] MADDOX, S. J., 1991. Fatigue strength of welded structures, Second Edition, Woodhead Publishing, UK, ISBN 978-1855730137.

[8] MATHERS, G., 2002. The welding of aluminium and its alloys. Published by Woodhead Publishing Limited, Abington Hall, Abington Cambridge CB1 6AH, England, ISBN 0-8493-1551-4.

[9] KALINCOVA, D. (2012). Analysis of welded joint of band-saw blade - influence of annealing process mechanical properties. Manufacturing Technology 2012, Vol. 12, No. 13, pp. 125-131, ISSN 1213-2489.

[10] PODREZ-RADZISZEWSKA M.: Weldability problems of the technical AW7020 alloy. Manufacturing Technology 2011, Vol. 9, No. 11, pp. 59-66, ISSN 1213-2489.

[11] SÁGA, M., KOPAS, P., VAŠKO, M.: Some computational aspects of vehicle shell frames optimization subjected to fatigue life. Communications. Vol. 12, No. 4, 2010, pp. 73-79, ISSN 1335-4205.

[12] SAPIETOVÁ, A., DEKÝŠ, V., VAŠKO, M. (2010). A numerical model of rotating machine having unbalance and the measurements of its dynamical properties. Metalurgija (Metalurgy) 2010, No. 2, Vol. 49, pp. 503-507, ISSN 0543-5846.

[13] SUSMEL, L., ASKES, H. Modified Wöhler Curve Method and multiaxial fatigue assessment of thin welded joints. International Journal of Fatigue 43, pp. 30-42.

[14] TREBUŇA, F., BURŠAK, M. (2002). Medzné stavy, lomy. Grafotlač, Prešov 2002. ISBN 807165-362-4. 
[15] ZHANG, D., WANG, Y. Experimental investigation on fatigue damage rule of LY12CZ aluminum alloy under tension-torsion loading. Journal of Mechanical Strength 34 (5), pp. 772-776.

[16] ŽMINDÁK, M., RIECKY, D. (2012). Meshless Modelling of Laminate Mindlin Plates under Dynamic Loads. In Communications. 2012, Vol. 14, No. 3, pp. 24-31. ISSN 1335-4205.

[17] KOVANDA, K., HOLUB, L., KOLAŘIK, L., KOLǍ̌IKOVA, M., VONDROUŠ, P. (2012). Experimental Verification of FEM Simulation of GMAW Bead on Plate Welding. Manufacturing Technology 2012, Vol. 12, No. 12 , pp. 30-33, ISSN 1213-2489. 